DOI https://doi.org/10.30525/978-9934-26-038-4-2

\title{
ОСОБЕННОСТИ КЛИНИЧЕСКИХ \\ ПРОЯВЛЕНИЙ ПОСТИНФАРКТНОГО РАЗРЫВА МЕЖЖЕЛУДОЧКОВОЙ ПЕРЕГОРОДКИ У ПАЦИЕНТОВ, ОПЕРИРОВАННЫХ В РАЗНЫЕ СРОКИ ОТ РАЗВИТИЯ ОСТРОГО ИНФАРКТА МИОКАРДА
}

\author{
Алиев Р. А. \\ кандидат медицинских наук, \\ врач-хирург сердечно-сосудистый \\ Клиника «Зеферан» \\ г. Баку, Азербайджан \\ Лебедева Е. О. \\ кандидат медииинских наук, \\ врач-хирург сердечно-сосудистый \\ ГУ «Национальный институт сердечно-сосудистой хирургии \\ имени Н. М. Амосова \\ Национальной академии медицинских наук Украины»» \\ 2. Киев, Украина \\ Груша М. М. \\ кандидат биологических наук, \\ доиент кафедры биологии \\ Национальный медицинский университет имени О. О. Богомольйа \\ г. Киев, Украина
}

Актуальность. Постинфарктный разрыв межжелудочковой перегородки (ПРМЖП) является одним из самых жизнеугрожающих механических осложнений острого инфаркта миокарда (ОИМ). Частота встречаемости ПРМЖП составляет $0,2-3 \%$ от общего числа пациентов с перенесенным ОИМ [1, с. 211], [2, с. 20]. В большинстве случаев ПРМЖП формируется в течение недели после развития ОИМ в условиях одно- или многососудистого атеросклеротического поражения коронарного русла [3, с. 687]. Формирование ПРМЖП создает условия для сброса крови в правые отделы сердца, что приводит к серьезным нарушениям внутрисердечной гемодинамики. Перегрузка легких, правого и поврежденного инфарктом левого желудочков приводят к развитию застойной сердечной недостаточности $(\mathrm{CH})$ [4, с. 1592], 
[5, с. 1422]. При этом, более чем у половины больных $(54,8 \%)$ развитие ПРМЖП происходит на фоне клинического благополучия постинфарктного периода [6, с. 16], что значительно снижает настороженность медицинского персонала о возможности развития такого осложнения ОИМ. В настоящее время только хирургическая коррекция ПРМЖП является методом выбора, поскольку возможности медикаментозной терапии при этом осложнении ОИМ крайне ограничены и малоэффективны. В тоже время, высокий уровень смертности пациентов, особенно при коррекции дефекта межжелудочковой перегородки (МЖП) в ранние сроки после развития ОИМ, оставляет открытым вопрос о тактике их хирургического лечения [7, с. 2061]. Учитывая непредсказуемость течения ПРМЖП, представляется целесообразным изучение клинического состояния таких пациентов, способное определить тактику хирургического вмешательства и его прогноз. Не менее актуальным является вопрос о влиянии различной локализации ПРМЖП на клиническое течение ишемической болезни сердца (ИБС) у таких пациентов.

Цель: оценить клиническое состояние пациентов с ПРМЖП в зависимости от сроков выполнения хирургического вмешательства после развития ОИМ и локализации дефекта МЖП для определения наиболее оптимального времени выполнения его коррекции.

Материал и методы: В работе представлен анализ 90 больных ИБС, осложненной ПРМЖП, выполненный ретроспективно после выполнения хирургического вмешательства. Все пациенты с ПРМЖП были распределены на группы в зависимости от сроков хирургического вмешательства после перенесенного ОИМ: 1 группа до 28 дней $(\mathrm{n}=28)$; 2 группа от 29 до 56 дней $(\mathrm{n}=26) ; 3$ группа от 57 и больше дней $(\mathrm{n}=36)$. Кроме того, при анализе учитывалась локализация ПРМЖП (передняя $(\mathrm{n}=51)$ и задняя $(\mathrm{n}=39))$. Обследование пациентов с ПРМЖП проводилось с использованием общеклинических методов исследования. При проведении статистического анализа данных были использованы точный тест Фишера (Fisher's Exact Test) и критерий согласия Пирсона $(\chi 2$ тест).

Результаты. Общеклиническое обследование пациентов с ПРМЖП указывает на наличие статистически значимых различий как в частоте возникновения признаков острой $\mathrm{CH}(\mathrm{p}<0,001)$, так и хронической недостаточности кровообращения $(\mathrm{p}<0,001)$ у пациентов с разными сроками от развития ОИМ. Нарастание частоты возникновения отеков и проявления увеличения печени $(\mathrm{p}=0,002)$ у пациентов исследуемых групп свидетельствует о прогрессировании $\mathrm{CH}$ по мере увеличения 
срока от развития ОИМ. Последнее, в совокупности с выявленным у большинства пациентов с ПРМЖП грубым систолическим шумом с локализацией в 4-м межреберье слева, являются одними из основных клинических проявлений возникновения разрыва МЖП. В тоже время, уменьшение частоты выявления признаков цианоза во 2-й и 3-й группах $(\mathrm{p}<0,001)$ и одышки в состоянии покоя $\left(\chi^{2}(2, \mathrm{n}=87)=9,534\right.$; $\mathrm{p}=0,009)$ свидетельствует в пользу развития компенсаторных механизмов, направленных на улучшение оксигенации периферических органов и тканей. Таким образом, вероятность выявления признаков развития компенсаторных механизмов (исчезновение одышки в покое, уменьшение или исчезновение признаков цианоза) возрастает по мере увеличения срока от развития ОИМ. Указанное согласуется с наличием статистически значимой связи между толерантностью к физической нагрузке $\left(\chi^{2}(2, n=62)=8,350 ; p=0,015\right)$, тяжестью клинического состояния пациентов с ПРМЖП $\left(\chi^{2}(2, n=84)=9,788 ; p=0,007\right)$ и временем от развития ОИМ. Результаты общеклинического обследования пациентов с различной локализацией ПРМЖП свидетельствуют о более существенном влиянии фактора времени от развития ОИМ на тяжесть клинического течения ИБС нежели локализации дефекта МЖП.

Выводы: Формирование ПРМЖП приводит к перегрузке правых отделов сердца с последующим развитием бивентрикулярной недостаточности. Выявление в раннем постинфаркном периоде признаков прогрессирования правожелудочковой недостаточности и/или грубого систолического шума с локализацией в 4-м межреберье слева может выступать одним из основных клинических проявлений ПРМЖП. Таким образом, при выборе оптимального времени выполнения коррекции ПРМЖП необходимо учитывать индивидуальные темпы как включения компенсаторных механизмов в сердце, так и возникновения бивентрикулярной недостаточности, степень которых возрастает по мере увеличения сроков от развития ОИМ.

\section{Литература:}

1. Шевченко О.П. Осложнения инфаркта миокарда: разрыв межжелудочковой перегородки. Ииемическая болезнь сердиа / О.П. Шевченко, О.Д. Мишнев. Москва, 2005. С. 211-216.

2. Khan M.Y., Waqar T., Qaisrani P.G. Surgical Repair of post-infarction ventricular septal rupture: Determinants of operative mortality and survival outcome analysis. Pakistan Journal of Medical Sciences. 2018. Vol. 34. № 1. P. 20-26. 
3. Simon Maltais, Reda Ibrahim, Arsène-Joseph Basmadjian. Postinfarction Ventricular Septal Defects: Towards a New Treatment Algorithm? The Annals of Thoracic Surgery. 2009. Vol. 87. № 3. P. 687-93.

4. Poulsen S.H., Praestholm M., Munk K. Ventricular septal rupture complicating acute myocardial infarction: clinical characteristics and contemporary outcome. The Annals of Thoracic Surgery. 2008. Vol. 85. P. 1591-1596.

5. Papadopoulos N., Moritz A., Dzemali O. Long-term results after surgical repair of postinfarction ventricular septal rupture by infarct exclusion technique. The Annals of Thoracic Surgery. 2009. Vol. 87. № 5. P. 1421-1425.

6. Виноградов А. В., Чекарева Г. А., Арутюнов Г. П. Динамика развития очага некроза по данным определения активности фракции МВ КФК и прекардиального картирования. Кардиология. 1981. № 9. C. 14-17.

7. Jones B.M., Kapadia S.R., Smedira N.G. Ventricular septal rupture complicating acute myocardial infarction: a contemporary review. European Heart Journal. 2014. Vol. 35. P. 2060-2068.

DOI https://doi.org/10.30525/978-9934-26-038-4-3

\title{
ЗМІНИ ПСИХОЕМОЦІЙНОГО СТАТУСУ У ПАЦІЕНТІВ 3 ОЖИРІННЯМ ПІД ВПЛИВОМ ЗАСОБІВ ФІЗИЧНОЇ ТЕРАПІЇ
}

\author{
Аравіцька М. Г. \\ кандидат медичних наук, дочент, \\ доиент кафедри фізичної терапії, ерготерапії \\ Прикарпатський національний університет імені Василя Стефаника \\ м. Івано-Франківськ, Украӥна
}

Вступ. Психологічні та психопатологічні фактори відіграють велику роль у генезі ожиріння. Серед них особлива увага приділяється психічному стресу, емоційним та когнітивним порушенням, аномаліям особистості, розладам харчової та соціально зумовленим стереотипам поведінки [2, с. 252]. У хворих з індексом маси тіла $>25$ кг/м² зростає ризик виявлення психопатологічних розладів, а у більш ніж у половини пацієнтів $з$ морбідним ожирінням (МО) виявляються психічні порушення [4, c. 162]. 